Original Research

\title{
Phthalic Acid Esters Increased Activation of Urease by Altering the Molecular Conformation
}

\author{
Chen Wenjing ${ }^{1,2,3}$, Hu Yunlong, ${ }^{1,2}$ Wang Zhigang1, 2,3*, Xu Weihui ${ }^{1,2}$
}

${ }^{1}$ Heilongjiang Provincial Technology Innovation Center of Agromicrobial Preparation Industrialization, Qiqihar, 161006, China

${ }^{2}$ College of Life Sciences, Agriculture and Forestry, Qiqihar University, Heilongjiang Province, Qiqihar 161006, China ${ }^{3}$ Center for Ecological Research, Northeast Forestry University, Heilongjiang Province, Harbin 150040, China

Received: 31 January 2021

Accepted: 14 April 2021

\begin{abstract}
Phthalic acid esters (PAEs), including dimethyl phthalate (DMP) and dibutyl phthalate (DBP), were widely known by their potential biological toxicity. In this work, the interaction between PAEs and urease was studied by the resonance light scattering spectrum (RLS), average particle size, molecular docking, molecular dynamics simulation, enzyme activity assay and reaction kinetic experiment. Both DMP and DBP could form stable complexes with urease, and enhance the rigidity and stability of urease. The RLS and average particle size of urease were decreased by DMP and DBP. Moreover, the activation mechanism was non-competitive activation mechanism because $K_{m}$ of urease kept the same and $V_{\max }$ were increased. It could be concluded that PAEs altered the molecular conformation of urease and increased the urease activity by the non-competitive activation mechanism.
\end{abstract}

Keywords: phthalic acid esters, urease, catalytic domain, non-competitive activation, binding forces

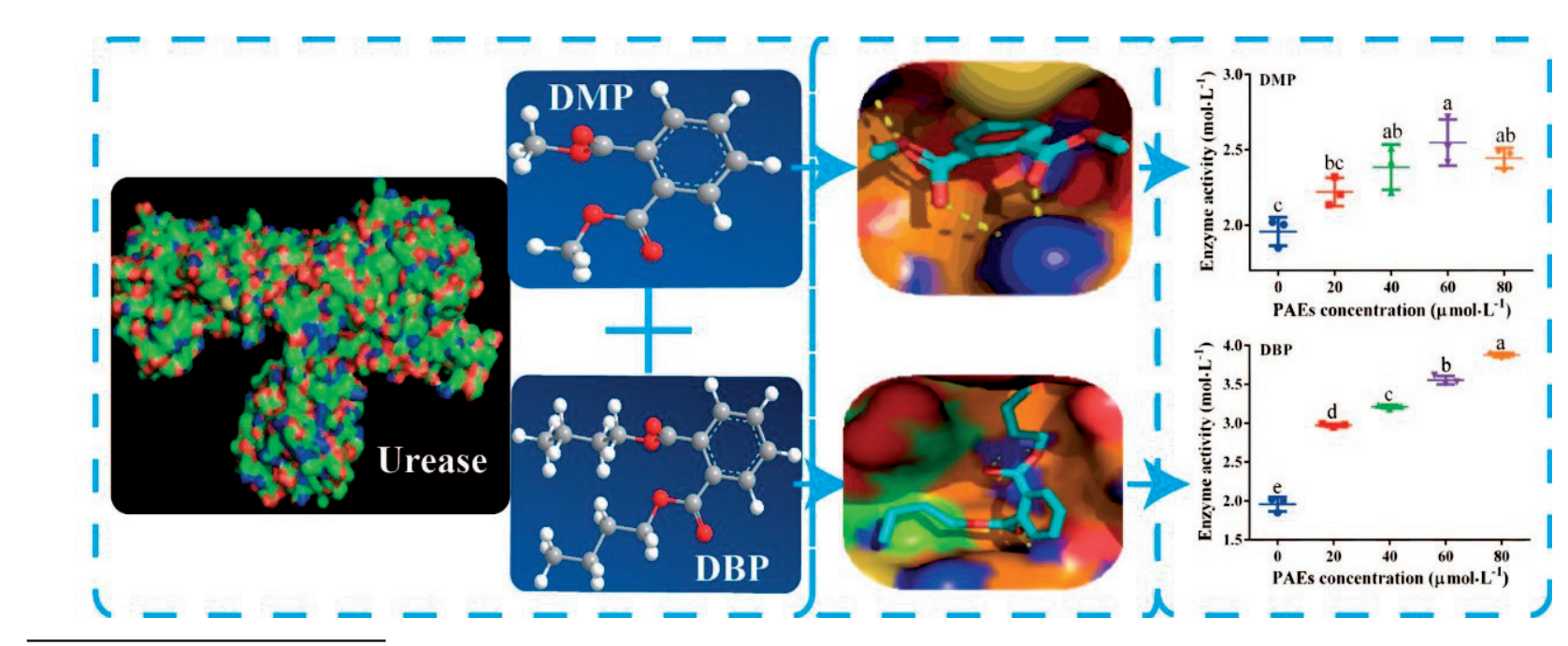

*e-mail: wangzhigang@qqhru.edu.cn 


\section{Introduction}

Urease in plants and microbes is characterized by being a nickel-based enzyme, and the amino acid sequences and active-site architecture of plant urease are similar to that of bacterial urease [1]. Furthermore, urease is regarded as being one of the most vital enzymes in supplying nitrogen for the metabolism in living organisms, being used to catalyze the transformation of urea to carbon dioxide and ammonia [2-5].

Phthalic acid esters (PAEs) were widely used as plasticizers $[6,7]$, and detected in air, water, sediments, soil and food [8-11] because of the relatively weak interactions between PAEs and plastics [12]. For humans, the number and quality of spermatozoon motility were significantly decreased and the risk of breast cancer and prostate cancer were increased with PAEs environmental exposure [6]. Additionally, because of the mutagenicity, teratogenicity and carcinogenicity of PAEs [13-16], dimethyl phthalate (DMP) and dibutyl phthalate (DBP) have been listed as priority pollutants by both the China National Environmental Monitoring Centre and the United States Environmental Protection Agency [17].

PAEs could bind with human serum albumin (HSA) during transport and metabolic processes in vitro, and the combination of PAEs induced a conformational change of HAS [18]; the combination of DBP with trypsin could possibly cause competitive inhibition of trypsin [19]. In this study, the impacts of DMP and DBP on activity of urease were researched by the resonance light scattering spectrum (RLS), average particle size, molecular docking, molecular dynamics simulation, enzyme activity assay and reaction kinetic experiment, which should illuminate the toxicological profile of PAEs in living organism.

\section{Materials and Methods}

\section{Materials}

Jack bean urease (urea amidohydrolase, EC 3.5.1.5), with an activity of $1.02 \mathrm{U} / \mathrm{mg}$, was purchased from Yuanye Biology (Shanghai, China) and directly dissolved in ultrapure water to prepare the stock solution $\left(1.5 \times 10^{-5} \mathrm{~mol} / \mathrm{L}\right)$.

DMP and DBP $(>99.5 \%)$ were purchased from Guangfu Chemical Research Institute (Tianjin, China) and the stock solutions $\left(5 \times 10^{-3} \mathrm{~mol} / \mathrm{L}\right)$ were prepared in acetone $(99.5 \%)$ at a ratio of $1: 9(\mathrm{~m} / \mathrm{m})$.

Phosphate buffer (PBS buffer, $0.2 \mathrm{~mol} / \mathrm{L}, \mathrm{pH}=7.5$ ) was used to control the $\mathrm{pH}$ value.

\section{Resonance Light Scattering Spectrum (RLS) Assays}

For $5 \mathrm{~mL}$ reaction system, $4 \mathrm{~mL}$ of a $1.5 \times 10^{-5} \mathrm{~mol} / \mathrm{L}$ urease solution was treated with $0,20,40,60$ and $80 \mu \mathrm{L}$

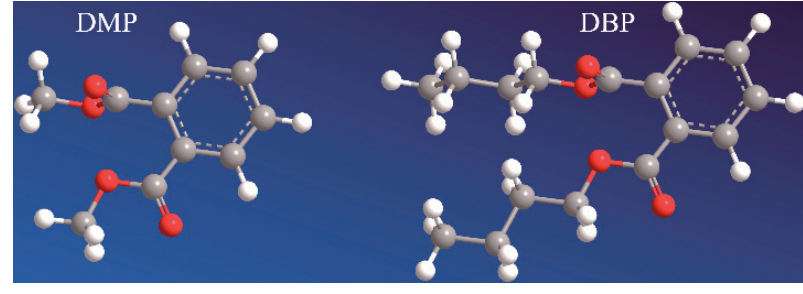

Fig. 1. Molecular structures of DMP and DBP.

of $5 \times 10^{-3} \mathrm{~mol} / \mathrm{L}$ PAEs solution, respectively, incubated at $298 \mathrm{~K}$ for $30 \mathrm{~min}$, and then the measurement of RLS was performed using a F-7000 fluorescence spectrophotometer (Hitachi, Japan) at a $2.5 \mathrm{~nm}$ slit width and $700 \mathrm{~V}$ voltage. Finally, a RLS was measured at $\lambda \mathrm{ex}=\lambda \mathrm{em}$ from $200 \mathrm{~nm}$ to $600 \mathrm{~nm}[20,21]$.

\section{The Measurements of Average Particle Size}

The solution systems were consistent with the RLS spectra assay. After incubating at $298 \mathrm{~K}$ for $30 \mathrm{~min}$, the average particle size measurement was carried out using a Zetasizer Nano ZS90 (Malvern, Britain) at a $4 \mathrm{~mW}, 633 \mathrm{~nm}$ He-Ne laser and the size mode [22].

\section{Molecular Docking Studies}

The effect of PAEs on the binding strength of the urease was carried out on AutoDock 4.0 (The Scripps Research Institute, USA). The structure of urease (PDB code: 3LA4) was obtained from RCSB Protein Data Bank (https://www.rcsb.org/) and the standard 3D structure (PDB format) of PAEs were obtained with Chem3D Ultra 14.0 software (Cambridge soft corporation, Britain). After removing water molecules, adding all hydrogen atoms, calculating Gasteiger charges and merging non-polar hydrogen atom, the PDB files were transferred to PDBQT files, and the blind docking was carried out with the grid box of $60 \AA$ size $(x, y, z)$ at a spacing of $0.6 \AA$. the grid box had dimensions of 127, 121 and $125 \AA$ ( $\mathrm{x}, \mathrm{y}$, and $\mathrm{z}$, respectively) at a spacing of 0.375 $\AA$. The 2D and cartoon analyses were performed the lowest energy conformations using PyMol molecular graphics system (DeLano Scientific LLC, California, USA) [23].

\section{Molecular Dynamics Simulation}

Molecular dynamics simulations of urease and the protein-ligand complexes (urease-DMP, urease-DBP) from the molecular docking results were performed using Discovery Studio (Accelrys, Inc. San Diego, CA). The solvation environment was $0.145 \mathrm{mmol} / \mathrm{L}$ saline [24]. The root-mean-square deviation (RMSD) value was determined through solvation, heating, equilibrium and production stages. 

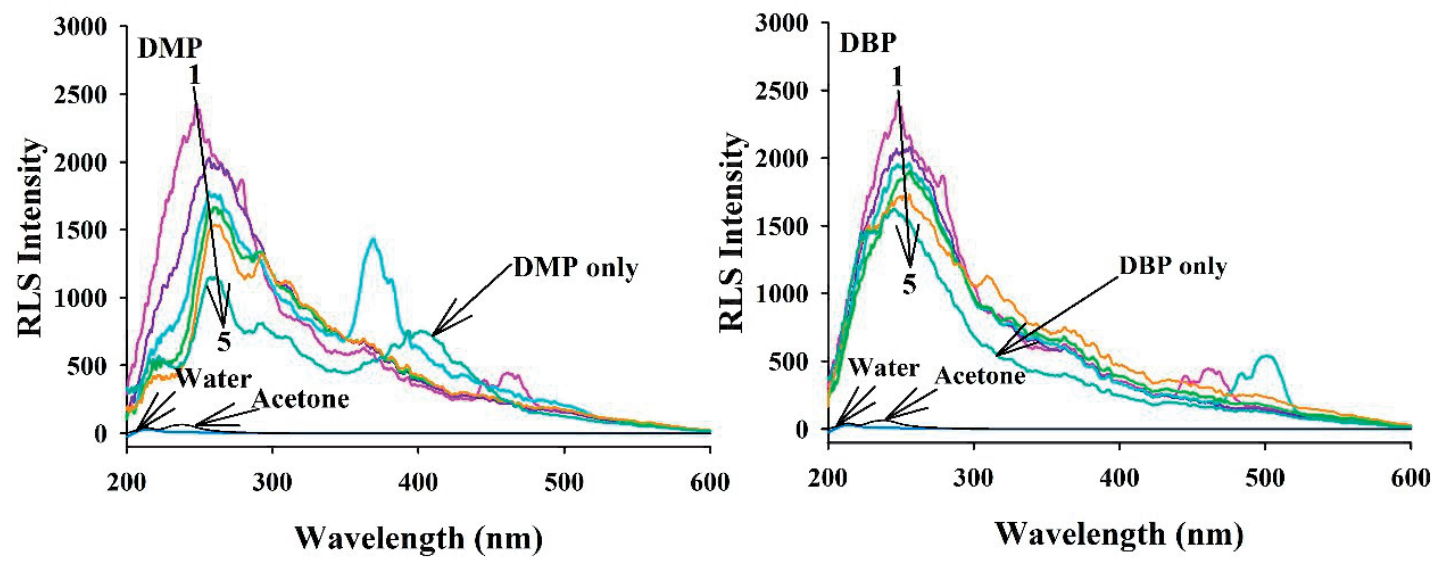

Fig. 2. The effects of DMP or DBP with varied concentrations on the resonance light scattering spectrum of urease $(\mathrm{T}=298 \mathrm{~K}, \mathrm{pH} 7.5)$. Conditions: $\mathrm{C}_{\text {urease }}=1 \mu \mathrm{mol} / \mathrm{L} ; \mathrm{C}_{\mathrm{PAEs}} 1-5: 0,20,40,60$, and $80 \mu \mathrm{mol} / \mathrm{L}$, respectively.

\section{Urease Activity Assays and Reaction Kinetic Experiments}

$4 \mathrm{~mL}$ of a $1.5 \times 10^{-5} \mathrm{~mol} / \mathrm{L}$ urease solution was treated with $0,20,40,60$ and $80 \mu \mathrm{L}$ of $5 \times 10^{-3} \mathrm{~mol} / \mathrm{L}$ PAEs solution, respectively, incubated at $298 \mathrm{~K}$ for $30 \mathrm{~min}$, and then added $1 \mathrm{~mL}$ of $0.10 \mathrm{~mol} / \mathrm{L}$ urea to reaction system. Then, PBS buffer $(0.2 \mathrm{~mol} / \mathrm{L}, \mathrm{pH}=7.5)$ was added to make a final volume of $6 \mathrm{~mL}$. After incubating at 298 for $6 \mathrm{~h}$, the urease activity was measured with indophenol blue colorimetric method at $578 \mathrm{~nm}$ using a UV 1100 spectrophotometer (Mei puda, China). Finally, a calibration curve was generated to measure the absorbance of ammonium at $578 \mathrm{~nm}$ [25].

Reaction kinetic was applied to research the interaction mechanism between the urease and the PAEs. By measuring the values of enzyme activity for urea with varied concentrations $(0.025,0.050,0.075$, and $0.100 \mathrm{~mol} / \mathrm{L}$ ), and the kinetic constants of MichaelisMenten constant $\left(K_{m}\right)$ and maximum velocity $\left(V_{\max }\right)$ are described by the Lineweaver-Burk equation $[26,27]$.

$$
\frac{1}{\mathrm{~V}}=\frac{K_{m}}{V_{\max }} \times \frac{1}{[\mathrm{~S}]}+\frac{1}{V_{\max }}
$$

...where $\mathrm{V}$ is the initial velocity, $[\mathrm{S}]$ is the substrate concentration.

\section{Statistical Analysis}

All statistical analyses were conducted by SPSS 22.0 (IBM, USA). The differences were determined using the Tukey HSD's multiple range tests, with $p<0.05$ denoting significance.

\section{Results and Discussion}

Resonance Light Scattering Spectrum (RLS)

RLS was carried out for studying the change on particle volume of urease because the RLS intensity was positively correlated with the square of the volume of particles [28, 29]. The RLS of urease under DMP or DBP with varied concentrations are shown in
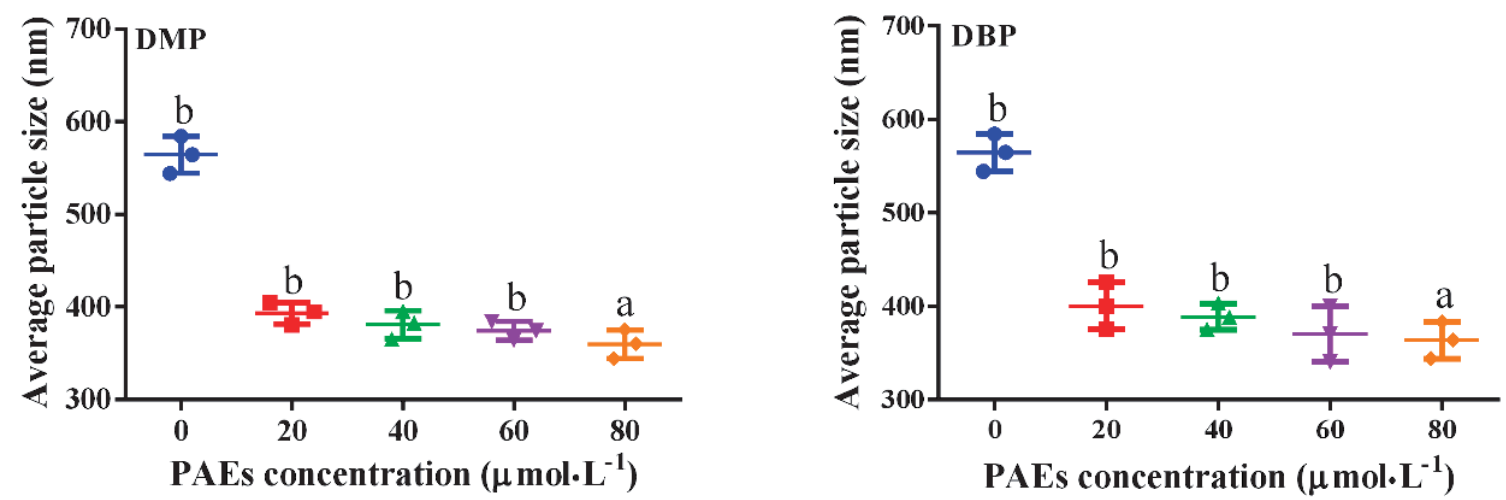

Fig. 3. The effects of DMP or DBP with varied concentrations on the average particle size of urease ( $\mathrm{T}=298 \mathrm{~K}, \mathrm{pH} 7.5)$. Conditions: $\mathrm{C}_{\text {urease }}=1 \mu \mathrm{mol} / \mathrm{L} ; \mathrm{C}_{\mathrm{PAEs}}: 0,20,40,60$, and $80 \mu \mathrm{mol} / \mathrm{L}$, respectively. Different letters denote significant differences at $p<0.001$. 


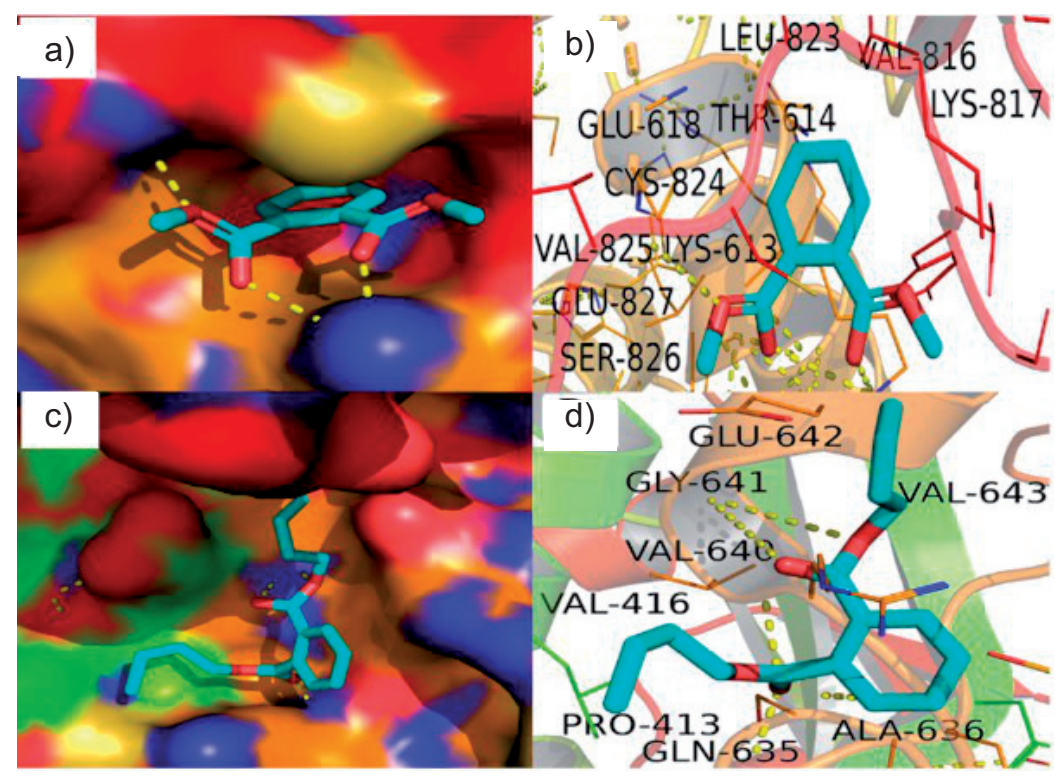

Fig. 4. Molecular docking of urease exposed to $\operatorname{DMP}(A, B)$ or DBP (c, d). The enzyme surface (a, c) and cartoon modes (b, d) of ureasePAEs.

Fig. 2. The RLS intensity of urease decreased at 248 nm with adding of DMP or DBP. The combination of potassium dichromate with bovine serum albumin (BSA) destroyed the protecting water of BSA and induced more dispersion, as well as the reduction of particle size [30]; Bisphenol A changed the structure and even stripped the lid and solvent shell, resulting in reducing the molecule size of candida rugosa lipase [17]. Therefore, the results suggested that the size of the urease molecule could be reduced and exposed to DMP or DBP by breaking the protecting water or depriving the lid or the solvent shell on the surface of urease.

\section{The Average Particle Size of Urease}

The average particle size as an effective method to evaluate the dimensions of macromolecular compound, and further confirm the conformational changes of urease with the addition of PAEs. The effects of DMP or DBP with varied concentrations on the average particle size of urease are shown in Fig. 3. The size of urease decreased significantly with the addition of DMP or DBP, which could result from the reduction of the size of urease molecules [17]. This result also further confirmed the results of RLS.

The results of RLS and average particle size assay showed that the size of the urease molecule was reduced by DMP or DBP. Thereby, the addition of PAEs changed the conformation of the catalytic domain and became exposed easily to the substrate, and then the activity of urease was changed [17, 27].

\section{Molecular Docking}

The binding information between the protein and the ligand was obtained from molecular docking simulations using a AutoDock 4.0 software. In the precious study, PAEs can bind with human serum albumin (HSA), and the PAEs molecule is situated within both binding sites in sub-domain IIIA. However, the binding of PAEs to site II produced lower free energy, which makes the binding more stable [18]. Therefore, the minimum energy was the most optimal orientation $[12,31]$, and the results for which are shown in Fig. 4. In Fig. 4a) and 4c), DMP and DBP could interact with the urease, and the binding force of DMP with urease $\left(-\Delta G_{\text {binding }}: 5.46 \mathrm{kcal} / \mathrm{mol}\right)$ was higher than that of DBP-urease $\left(-\Delta G_{\text {binding }}: 5.23 \mathrm{kcal} / \mathrm{mol}\right)$. According to different binding structure, the increase of the chain lengths is accompanied by a decrease in binding affinities [23]; The value of $\Delta G_{\text {binding }}$ increased with the binding force decreased, when the length of alkyl chain of PAEs increased [20]. Therefore,

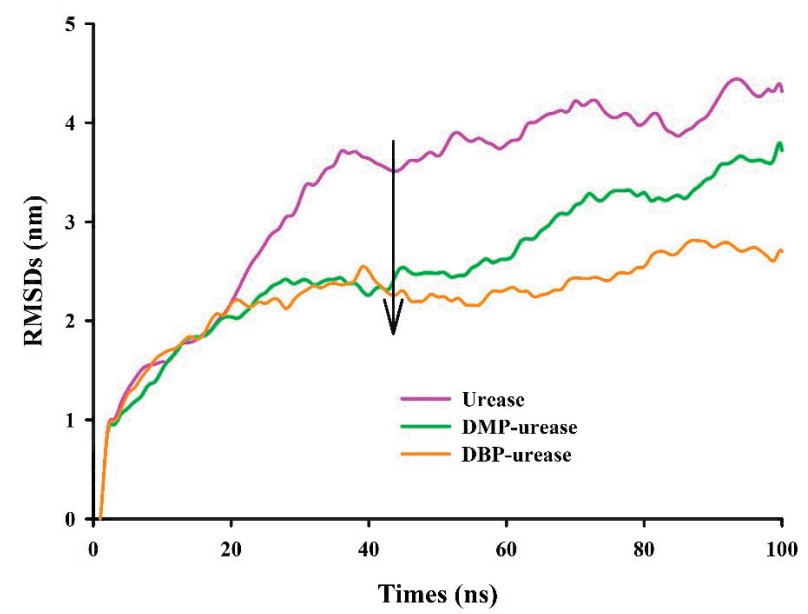

Fig. 5. RMSDs for urease and urease-PAEs complexes. 

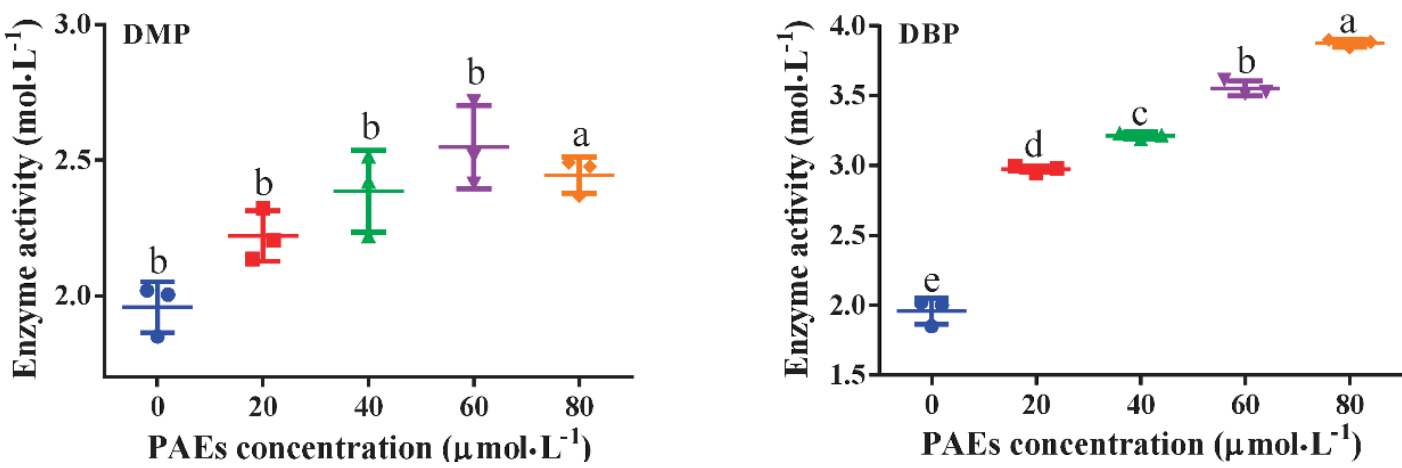

Fig. 6. The effects of DMP and DBP with varied concentrations on the activity of urease $(\mathrm{T}=298 \mathrm{~K}, \mathrm{pH} 7.5)$. Conditions: $\mathrm{C}_{\text {urease }}=1$ $\mu \mathrm{mol} / \mathrm{L} ; \mathrm{C}_{\mathrm{PAES}}: 0,20,40,60$, and $80 \mu \mathrm{mol} / \mathrm{L}$. Different letters denote significant differences at $p<0.001$.

Table 1. The effects of DMP and DBP with varied concentrations on urease kinetic parameters.

\begin{tabular}{|c|c|c|c|c|}
\hline \multirow{2}{*}{ PAEs concentration $(\mu \mathrm{mol} / \mathrm{L})$} & \multicolumn{2}{|c|}{ DMP } & \multicolumn{2}{c|}{ DBP } \\
\cline { 2 - 5 } & $K_{m}(\mu \mathrm{mol} / \mathrm{L})$ & $V_{\max }(\mu \mathrm{mol} / \mathrm{L} / \mathrm{h})$ & $K_{m}(\mu \mathrm{mol} / \mathrm{L})$ & $V_{\max }(\mu \mathrm{mol} / \mathrm{L} / \mathrm{h})$ \\
\hline 0 & 0.01 & 0.21 & 0.01 & 0.21 \\
\hline 20 & 0.01 & 0.21 & 0.01 & 0.28 \\
\hline 40 & 0.01 & 0.26 & 0.01 & 0.31 \\
\hline 60 & 0.01 & 0.27 & 0.01 & 0.32 \\
\hline 80 & 0.01 & 0.37 & 0.01 & 0.33 \\
\hline
\end{tabular}

DMP had the strongest binding affinity to urease [32].

The results presented in Fig. 4b) showed that DMP interacted with the urease via van der Waals interactions with LYS-612, SER-826, LEU-822, LEU-823 and THR-815; hydrogen bonding with LYS-613, VAL-825 and CYS-824; and pi-pi pairing with ALA-617, VAL-816, ALA-616, LYS-613 and CYS-824. As shown in Fig. 4d), DBP interacted with urease via van der Waals interactions with CYS-412 and LEU-415; hydrogen bonding with GLN-635, GLY-641, VAL-640, SER-634 and GLU-642; pi-pi pairing with Arg-639. DMP and DBP can interact with urease and form a stable complex via pi interactions $[12,33]$.

\section{Molecular Dynamics Simulation}

Molecular dynamics simulation is well-recognized as a powerful tool to investigate the changes in the protein-ligand system at the atomic level and highlight the stability of the complex [12, 34]. Commonly, molecular dynamics simulation allows the calculation of root mean square deviation (RMSD) values, which show one of the most useful and straightforward features for structural comparison between different conformations of the same molecule [35], and as shown in Fig. 5, the total energy for the molecular systems of the DMP-urease complex, DBP-urease and the urease remained stable, with some fluctuations occurring after $40 \mathrm{~ns}$ of simulation, and the relative decrease in the RMSD values of the complexes with respect to free urease indicated that DMP and DBP altered the conformation and increased the rigidity and stability of the urease $[12,18]$.

\section{Urease Activity Assay and Reaction Kinetic Experiment}

The activity of enzyme, which is related to its certain folds and any conformational changes, may change its catalytic functions [17], as shown in Fig. 6, the activities of urease raised significantly by DMP contamination, except that the $20 \mu \mathrm{mol} / \mathrm{L}$ DMP, the activities of urease increased non significantly. With the contamination of DBP, the activities of urease raised significantly. The protein activity rose with the increase of dicofol (DCF) concentration indicated that the change of protein's conformation results in the incremental activity [31]. In addition, the bisphenol A (BPA) molecule combined with residue Ser-209 of active site of candida rugosa lipase (CRL), the whole structure of the catalytic triad could be altered and became more exposed to the substrate [17]. Therefore, the activities raised of urease implied that the change of protein's conformation.

The activator types of DMP and DBP on the activity of urease were also investigated. As shown in Table 1, 
with the increased in concentrations of DMP and DBP, $K_{m}$ unchanged and $V_{\max }$ increased, which fit the characteristic of noncompetitive activation.

The structure of the noncompetitive activator is not similar to the enzyme substrate, however, it can combine with an enzyme molecule group to improve the space structure of the enzyme, and change the conformation of the catalytic domain [27], in agreement with the results of the resonance light scattering spectrum, average particle size assay, molecular docking and molecular dynamics simulation.

\section{Conclusion}

Based on the above results, we concluded that the binding between the PAEs and the urease altered the molecular conformation and increased the enzymatic activity of urease by a non-competitive activation mechanism.

\section{Acknowledgements}

This work was supported by National Natural Science Foundation of China (31870493 and 31670375) and Basic Research Fees of Universities in Heilongjiang Province, China (No. 135409103).

\section{Conflict of Interest}

The authors declare no conflict of interest.

\section{References}

1. BALASUBRAMANIAN A., PONNURAJ K. Crystal Structure of the First Plant Urease from Jack Bean: 83 Years of Journey from Its First Crystal to Molecular Structure. Journal of Molecular Biology. 400 (3), 274, 2010.

2. GUL R., RAUF M.K., BADSHAH A., AZAM S.S., TAHIR M.N., KHAN A. Ferrocene-based guanidine derivatives: In vitro antimicrobial, DNA binding and docking supported urease inhibition studies. European journal of medicinal chemistry. 85, 438, 2014.

3. IFTIKHAR F., ALI Y., AHMAD-KIANI F., FAHADHASSAN S., FATIMA T., KHAN A., NIAZ B., HASSAN A., LATIF-ANSARI F., RASHID U. Design, synthesis, in vitro Evaluation and docking studies on dihydropyrimidine-based urease inhibitors. Bioorg Chem. 74, 53, 2017.

4. RAUF A., SHAHZAD S., BAJDA M., YAR M., AHMED F., HUSSAIN N., AKHTAR M.N., KHAN A., JOŃCZYK J. Design and synthesis of new barbituric- and thiobarbituric acid derivatives as potent urease inhibitors: Structure activity relationship and molecular modeling studies. Bioorg Med Chem. 23 (17), 6049, 2015.

5. WU D.W., YU X.D., XIE J.H., SU Z.Q., SU J.Y., TAN L.R., HUANG X.Q., CHEN J.N., SU Z.R. Inactivation of jack bean urease by scutellarin: elucidation of inhibitory efficacy, kinetics and mechanism. Fitoterapia. 91, 60, 2013.

6. ARFAEINIA L., DOBARADARAN S., NASRZADEH F., SHAMSI S., POURESHGH Y., ARFAEINIA H. Phthalate acid esters (PAEs) in highly acidic juice packaged in polyethylene terephthalate (PET) container: Occurrence, migration and estrogenic activity-associated risk assessment. Microchemical Journal. 155, 104719, 2020.

7. HU X.Y., WEN B., SHAN X.Q. Survey of phthalate pollution in arable soils in China. Journal of Environmental Monitoring. 5 (4), 649, 2003.

8. BLAIR J.D., IKONOMOU M.G., KELLY B.C., SURRIDGE B., GOBAS F.A. Ultra-trace determination of phthalate ester metabolites in seawater, sediments, and biota from an urbanized marine inlet by LC/ESI-MS/MS. Environ Sci Technol. 43 (16), 6262, 2009.

9. CHEN C., CHEN C., DONG C. Distribution of Phthalate Esters in Sediments of Kaohsiung Harbor, Taiwan. Soil and Sediment Contamination: An International Journal. 22 (2), 119, 2013

10. WANG J., BO L., LI L., WANG D., CHEN G., CHRISTIE P., TENG Y. Occurrence of phthalate esters in river sediments in areas with different land use patterns. Science of The Total Environment. 500, 113, 2014.

11. XU D., DENG X., FANG E., ZHENG X., ZHOU Y., LIN L., CHEN L., WU M., HUANG Z. Determination of 23 phthalic acid esters in food by liquid chromatography tandem mass spectrometry. Journal of Chromatography A. 1324 (1), 49, 2014.

12. CHEN W., WANG Z., XU W., TIAN R., ZENG J. Dibutyl phthalate contamination accelerates the uptake and metabolism of sugars by microbes in black soil. Environmental Pollution. 262, 114332, 2020.

13. JUREWICZ J., HANKE W. Exposure to phthalates: Reproductive outcome and children health. A review of epidemiological studies. International Journal of Occupational Medicine and Environmental Health. 24 (2), 115, 2011.

14. MA T.T., CHRISTIE P., LUO Y., TENG Y. Phthalate esters contamination in soil and plants on agricultural land near an electronic waste recycling site. Environmental Geochemistry and Health. 35 (4), 465, 2013.

15. YE T., KANG M., HUANG Q., FANG C., CHEN Y., SHEN H., DONG S. Exposure to DEHP and MEHP from hatching to adulthood causes reproductive dysfunction and endocrine disruption in marine medaka (Oryzias melastigma). Aquatic Toxicology. 146, 115, 2014.

16. ZHANG Y., WANG P., WANG L., SUN G., ZHAO J., ZHANG H., DU N. The influence of facility agriculture production on phthalate esters distribution in black soils of northeast China. Science of The Total Environment. 506, 118, 2015.

17. WANG Z., LIU S., XU W., HU Y., HU Y., ZHANG Y. The microbiome and functions of black soils are altered by dibutyl phthalate contamination. Applied Soil Ecology. 99, $51,2016$.

18. WU Z., YI Z., DONG L., ZHANG A. Molecular simulation study of the specific combination between four kinds of phthalic acid esters and human serum albumin. Environmental Toxicology and Pharmacology. 41, 259, 2016.

19. CHI Z., ZHAO J., LI W., ARAGHI A., TAN S. In vitro assessment of phthalate acid esters-trypsin complex formation. Chemosphere. 185, 29, 2017. 
20. TAN S., TAN X., CHI Z., ZHANG D., LI W. In vitro assessment of the toxicity of lead $\left(\mathrm{Pb}^{2+}\right)$ to phycocyanin. Chemosphere. 192, 171, 2018.

21. ZHANG R., ZHAO L., LIU R. Deciphering the toxicity of bisphenol a to Candida rugosa lipase through spectrophotometric methods. Journal of Photochemistry and Photobiology B: Biology. 163, 40, 2016.

22. SOMAN S., CHACKO A.S., PRASAD V.S., ANJU P., SURYA B.S., VANDANA K. Self-assembly of oleylamine modified nano-fibrillated cellulose from areca husk fibers into giant vesicles. Carbohydrate polymers. 182, 69, 2018.

23. TAN S., CHI Z., SHAN Y., WEN Z., LI W. Interaction studies of polybrominated diphenyl ethers (PBDEs) with human serum albumin (HSA): Molecular docking investigations. Environmental toxicology and pharmacology. 54, 34, 2017.

24. RAMOS R.S., MACêDO W.J., COSTA J.S., DA-SILVA C.H.D.P., ROSA J.M., DA-CRUZ J.N., DE-OLIVEIRA M.S., DE-AGUIAR-ANDRADE E.H., E-SILVA R.B., SOUTO R.N. Potential inhibitors of the enzyme acetylcholinesterase and juvenile hormone with insecticidal activity: study of the binding mode via docking and molecular dynamics simulations. Journal of Biomolecular Structure and Dynamics. 1, 2019.

25. SONG Y., SONG C., TAO B., WANG J., ZHU X., WANG $\mathrm{X}$. Short-term responses of soil enzyme activities and carbon mineralization to added nitrogen and litter in a freshwater marsh of Northeast China. European Journal of Soil Biology. 61, 72, 2014.

26. AHMAD E., RABBANI G., ZAIDI N., AHMAD B., KHAN R.H. Pollutant-induced modulation in conformation and $\beta$-lactamase activity of human serum albumin. PloS one. 7 (6), e38372, 2012.

27. ZHENG J., ZHANG R.J., CHEN Y.M., YE X., CHEN Q.X., SHEN D.Y., WANG Q. Synthesis of caffeic acid ester morpholines and their activation effects on tyrosinase. Process Biochemistry. 62, 91, 2017.
28. PASTERNACK R.F., COLLINGS P.J. Resonance Light Scattering: A New Technique for Studying Chromophore Aggregation. Science. 269 (5226), 935, 1995.

29. SUN H., XIA Q., LIU R. Comparison of the binding of the dyes Sudan II and Sudan IV to bovine hemoglobin. Journal of Luminescence. 148, 143, 2014.

30. ZHANG P., LAN P., MA Y., GAO Y., CHEN H., FANG Q., ZONG W., LIU R. Spectroscopic investigation on the interaction of $\mathrm{Cr}(\mathrm{VI})$ with bovine serum albumin. Journal of Biochemical and Molecular Toxicology. 26 (2), 54, 2012.

31. LIU Y., CAO R., QIN P., LIU R. Assessing the potential toxic effect of one persistent organic pollutant: Noncovalent interaction of dicofol with the enzyme trypsin. Spectrochimica Acta Part A: Molecular and Biomolecular Spectroscopy. 89, 210, 2012.

32. KWOFIE S.K., DANKWA B., ENNINFUL K.S., ADOBOR C., BRONI E., NTIAMOAH A., WILSON M.D. Molecular docking and dynamics simulation studies predict munc18b as a target of mycolactone: A plausible mechanism for granule exocytosis impairment in Buruli Ulcer Pathogenesis. Toxins. 11 (3), 181, 2019.

33. CHANDRAVANSHI M., SHARMA A., DASGUPTA P., MANDAL S.K., KANAUJIA S.P. Identification and characterization of $\mathrm{ABC}$ transporters for carbohydrate uptake in Thermus thermophilus HB8. Gene. 696, 135, 2019.

34. HATA H., NISHIYAMA M., KITAO A. Molecular dynamics simulation of proteins under high pressure: Structure, function and thermodynamics. Biochimica et Biophysica Acta (BBA)-General Subjects. 1864 (2), 129395, 2020.

35. VELÁZQUEZ-LIBERA J.L., DURÁN-VERDUGO F., VALDÉS-JIMÉNEZ A., NÚÑEZ-VIVANCO G., CABALLERO J. LigRMSD: A web server for automatic structure matching and RMSD calculations among identical and similar compounds in protein-ligand docking. Bioinformatics. 36 (9), 2912, 2020. 
